\section{Discussion}

Because some patients on anticonvulsant drugs have low levels of serum folate ${ }^{128}$ and red cell folate ${ }^{9}$ most investigators have assumed that the macrocytosis that may develop in such patients is caused either by folate deficiency or by some interference with folate metabolism. The mechanisms that have been proposed to explain the low serum and red cell folate levels include $(a)$ an inadequate dietary intake of folate compounds, (b) an impaired absorption of folate monoglutamate from the diet, ${ }^{1-1: 2}$ (c) an impaired absorption of dietary folate polyglutamate as a consequence of the inhibition of folate conjugase by the $\operatorname{drug}(\mathrm{s}),{ }^{13 \cdot 15}$ (d) displacement of folate compounds from their carrier plasma proteins by the $\operatorname{drug}(\mathrm{s}),{ }^{*}(e)$ interference with the formation and function of intracellular folate coenzymes as a result of a structural similarity between folate coenzymes and anticonvulsant drugs, ${ }^{116}$ and $(f)$ increased utilisation of folate in the liver as a consequence of the involement of folate coenzymes in the detoxification of anticonvulsant drugs. ${ }^{9}$

Nine of the treated epileptics with megaloblastic erythropoiesis studied by us (including four patients with high MCVs) gave normal results in the deoxyuridine suppression test. Therefore, neither folate deficiency nor an interference with the 5,10 methylenetetrahydrofolate-dependent methylation of deoxyuridylate to thymidylate could be implicated in the pathogenesis of the macrocytosis and megaloblastic changes in these nine patients.

The results in cases 11 and 13 indicate that the bone marrow cells of some patients on anticonvulsant drugs do suffer from an abnormality in the methylation of deoxyuridylate. In case 13 this abnormality was partially corrected by the addition of $10 \mu \mathrm{g}$ pteroylglutamic acid per $\mathrm{ml}$ of marrow culture. As this concentration of pteroylglutamic acid corrects the abnormal deoxyuridine suppressed value in folate-deficient patients, ' and as the bone marrow cells in case 13 gave a normal deoxyuridine suppressed value after one month on an improved diet, it is likely that the abnormality in the methylation of deoxyuridylate detected in this case was caused by a dietary folate deficiency. The addition of $10 \mu \mathrm{g}$ pteroylglutamic acid per $\mathrm{ml}$ of marrow culture did not correct the abnormal deoxyuridine suppressed value in case 11, suggesting the possibility of some drug-induced interference with the methylation of deoxyuridylate. The elucidation of the mechanisms underlying the abnormal deoxyuridine suppressed values that are occasionally encountered in patients on antiepileptic drugs will require a study of a much larger group of treated epileptics.

The two patients giving abnormal results in the deoxyuridine suppression test had low red cell folate levels. Two other patients with low red cell folate levels (cases 2 and 14), however, gave normal results in the test. This discrepancy is reminiscent of the previously reported failure of most treated epileptics with low serum folate levels to excrete abnormal amounts of formiminoglutamic acid (figlu) in their urine after a loading dose of histidine. ${ }^{+17}$ Apparently the two folate-dependent metabolic steps investigated by the deoxyuridine suppression test and the figlu excretion test are sometimes unimpaired in treated epileptics, even when their serum and red cell folate levels have fallen below normal. The explanation for this is uncertain.

The megaloblastic changes and macrocytosis in patients giving normal results in the deoxyuridine suppression test are presumably caused by a direct effect of the anticonvulsant drugs or their metabolites on some biochemical step(s) other than the conversion of deoxyuridylate to thymidylate.

We thank Dr C H Edwards and Sir Roger Bannister for permission to study patients under their care.

\section{References}

${ }^{1}$ Hawkins, C F, and Meynell, M J, Quarterly fournal of Medicine, 1958, 27, 45.

2 Malpas, J S, Spray, G H, and Witts, L J, British Medical Fournal, 1966, $1,955$.

${ }^{3}$ Child, J A, Khattak, B Z, and Knowles, J P, British fournal of Haematology, 1969, 16, 451.

4 Reynolds, E H, et al, Quarterly fournal of Medicine, 1966, 35, 521.

${ }^{5}$ Herbert, V, et al, British fournal of Haematology, 1973, 24, 713.

${ }^{6}$ Wickramasinghe, S N, and Longland, J E, British Medical fournal, 1974, 3 148.

Wickramasinghe, S N, and Saunders, J E, British Medical Fournal, 1975, 2,87

${ }^{8}$ Klipstein, F A, Blood, 1964, 23, 68

${ }^{9}$ Maxwell, J D, et al, British Medical fournal, 1972, 1, 297.

10 Meynell, M J, Lancet, 1966, 1, 487.

${ }^{11}$ Benn, A, et al, British Medical fournal, 1971, 1, 148

1. Doe, W F, et al, British Medical fournal, 1971, 1, 669.

${ }_{13}$ Rosenberg, I H, et al, Lancet, 1968, 2, 530.

${ }^{14}$ Hoffbrand, A V, and Necheles, T F, Lancet, 1968, 2, 528.

15 Baugh, C M, and Krumdieck, C L, Lancet, 1969, 2, 519.

${ }^{16}$ Girdwood, R H, and Lenman, J A R, British Medical fournal, 1956, 1, 146.

17 Jensen, O N, and Olesen, O V, Archives of Neurology, 1969, 21, 208.

\title{
Continuous positive airway pressure and mechanical ventilation by facemask in newborn infants
}

\author{
L P ALLEN, A M BLAKE, G M DURBIN D INGRAM, E O R REYNOLDS, \\ $P$ D WIMBERLEY
}

British Medical fournal, 1975, 4, 137-139

\section{Summary}

During a nine-month period 24 newborn infants were treated with continuous positive airway pressure (CPAP)

University College Hospital and Medical School, London WC1

L P ALLEN, B SC, research student in medical physics

A $M$ BLAKE, RSCN, paediatric nursing officer

G M DURBIN, MRCP, lecturer in paediatrics

D INGRAM, BA, senior physicist

E O R REYNOLDS, FRCP, consultant paediatrician

P D WIMBERLEY, MRCP, senior paediatric registrar or mechanical ventilation delivered through a facemask. The mask was held in place in a way that minimised trauma and distortion of the head. The median birth weight of the infants was $1096 \mathrm{~g}$ and their median gestational age 29 weeks. The usual reason for treatment was hyaline membrane disease or recurrent apnoea due to inadequate control of breathing. Twenty-one of the infants survived. The technique was simple to apply and complications were minimal. We suggest that it may have advantages over other methods of applying CPAP or mechanical ventilation to infants mildly affected by respiratory illnesses and that it should be useful in avoiding endotracheal intubation or reducing the length of time that infants with more serious illnesses are intubated. 


\section{Introduction}

Continuous positive airway pressure $(\mathrm{CPAP})^{1}$ and mechanical ventilation are widely used for newborn infants with serious respiratory difficulties, particularly hyaline membrane disease and apnoea due to inadequate control of breathing. Infants with severe pulmonary illnesses usually require endotracheal intubation, but this has its dangers, such as trauma to the upper airway and problems with the removal of secretions. It is therefore important to dispense with the tube when possible. Various methods of applying CPAP include pressurised head-boxes, ${ }^{1}$ : plastic bags over the head, ${ }^{3}$ nasal cannulae, ${ }^{4-6}$ and facemasks. Mechanical ventilation has also been applied through facemasks, ${ }^{8}{ }^{9}$ and negative-pressure tanks have been used both for maintaining lung inflation during spontaneous breathing ${ }^{1} 011$ and for mechanical ventilation. ${ }^{10} 1213$

All these techniques have disadvantages. Head-boxes, plastic bags, and negative-pressure tanks make access to the infant difficult, and unless special care is taken the neck seal may obstruct cerebral venous return. ${ }^{14}$ Nasal cannulae are, in our experience, difficult to fix, and distortion of the nose and septal ulceration may occur. ${ }^{4} 6$ Facemasks may cause oedema of the face, and the strap used to hold them on may cause serious moulding of the head and cerebellar haemorrhage. ${ }^{8} 915$ Our method of holding a mask in place and applying CPAP and mechanical ventilation through it avoids these hazards. Because the method is simple and seems to be virtually without complications we here report our experience with it over nine months.

\section{Methods}

The facemask used was the Bennett infant mask, Nos 1-4, as used by Swyer et al. ${ }^{9}$ Usually a size was selected that fitted round the chin and upper part of the nose without pressing on the eyes. Occasionally a good fit could not be obtained in this way and a larger mask was applied round the forehead and chin. The mask was held in place with a piece of tubular elastic netting $8-10 \mathrm{~cm}$ long (Netelast $C$ or $D$, depending on the size of the head) stretched over the whole head (see fig). The edge of the mask was lifted periodically so that the pharynx could be cleared of secretions.

When CPAP was used a continuous flow of warmed humidified gas was passed through the mask at $4-81 / \mathrm{min}$ to a water manometer, expiratory resistance being provided by a $500-\mathrm{ml}$ anaesthetic bag wth a screw clamp on its outlet for varying the CPAP. ${ }^{1}$ The pressure was 5-7 $\mathrm{cm} \mathrm{H}_{2} \mathrm{O}$ initially for hyaline membrane disease, and it was subsequently varied to maintain an arterial oxygen tension $\left(\mathrm{PaO}_{2}\right)$ of about $8.6 \mathrm{kPa}(65 \mathrm{~mm} \mathrm{Hg})$. Pressures above $10 \mathrm{~cm} \mathrm{H}_{2} \mathrm{O}$ were not used.

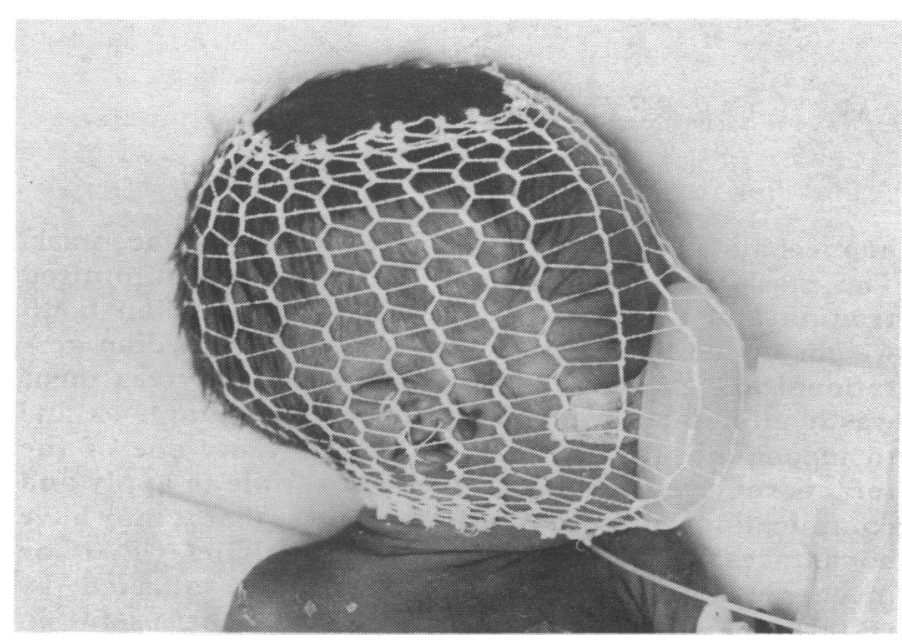

Mask CPAP being applied to infant weighing $734 \mathrm{~g}$ at 29 weeks of gestation. A No 1 Bennett infant facemask and Netelast tubular elastic netting were used. Tape coming from under mask was for fixing feeding tube.
For apnoea due to inadequate control of breathing a pressure of 3-4 $\mathrm{cm} \mathrm{H}_{2} \mathrm{O}$ was selected. ${ }^{6}$ When mechanical ventilation was required a Bennett PR2 or Drager Spiromat 661 ventilator was employed, the initial settings being usually as follows: peak airway pressure 12-15 $\mathrm{cm} \mathrm{H}_{2} \mathrm{O}$, end-expiratory pressure $0-2 \mathrm{~cm} \mathrm{H}_{2} \mathrm{O}$, respiratory frequency $30-40 / \mathrm{min}$, and inspiration :expiration ratio $1: 2$. These settings were altered as necessary to regulate $\mathrm{PaO}_{2}$ and $\mathrm{PaCO}_{2}$. When gastric distension developed, an open-ended $5 \mathrm{~F}$ feeding tube was passed.

\section{Infants}

Twenty-four infants (13 boys and 11 girls) were treated between 1 November 1974 and 31 July 1975. Twenty received mask CPAP, and 11 mask ventilation. Their median birth weight was $1096 \mathrm{~g}$ (range 638-2440 g) and their median gestational age 29 weeks (range 26-36 weeks). Nineteen were suffering from hyaline membrane disease, 10 from apnoea due to inadequate control of breathing, and two were hydropic from rhesus haemolytic disease.

The indication for starting mask CPAP in 10 infants with deteriorating hyaline membrane disease was a $\mathrm{PaO}_{2}$ less than $8.0 \mathrm{kPa}(60$ $\mathrm{mm} \mathrm{Hg}$ ) while the infant was breathing a fractional inspired oxygen $\left(\mathrm{FIO}_{2}\right)$ greater than $0 \cdot 6$. Five infants recovering from this illness who had been intubated for CPAP or mechanical ventilation were extubated and mask CPAP was substituted when their $\mathrm{PaO}_{2}$ was above $8.0 \mathrm{kPa}$ with an $\mathrm{FIO}_{2}$ of $0 \cdot 6-0.8$ and relatively low inflating pressures (CPAP $\leqslant 7 \mathrm{~cm} \mathrm{H}_{2} \mathrm{O}$; ventilator settings: peak airway pressure $\leqslant 20 \mathrm{~cm} \mathrm{H}_{2} \mathrm{O}$, end-expiratory pressure $\leqslant 3 \mathrm{~cm} \mathrm{H}_{2} \mathrm{O}$, inspiration:expiration ratio $\leqslant 1: 1$.) Six infants with apnoea due to inadequate control of breathing were treated with mask CPAP because they needed peripheral stimulation about five times an hour to prevent apnoea.

Mask ventilation was employed in 11 infants with normal or recovering lungs who could not sustain adequate spontaneous ventilation. Five of these infants were weaned from mask ventilation with mask CPAP.

\section{Results}

Details of treatment were entered, at the time they were obtained, into a PDP $11 / 45$ computer by means of a keyboard in the neonatal unit. These details were processed by the computer, and values for the age when treatment was started and stopped are given in the table.

Age when CPAP or mechanical ventilation $(M V)$ by facemask was started and stopped and total duration of treatment. Each infant received between 1 and 26 (median 1) episodes of treatment with $C P A P$ and $M V$

\begin{tabular}{ll|c|c}
\hline & \multicolumn{1}{c|}{$\begin{array}{c}\text { CPAP } \\
(\mathrm{n}=20)\end{array}$} & \multicolumn{1}{c}{$\begin{array}{c}M V \\
(\mathrm{n}=11)\end{array}$} \\
\hline \begin{tabular}{ll|l} 
Mean age at start (range) \\
$\begin{array}{l}\text { Mean duration of treatment (range) } \\
\text { Mean age at finish (range) }\end{array}$
\end{tabular} & $\cdots$ & $\begin{array}{l}91 \mathrm{~h}(3 \mathrm{~h}-14 \mathrm{~d}) \\
96 \mathrm{~h}(4 \mathrm{~h}-20 \mathrm{~d})\end{array}$ & $\begin{array}{l}8 \mathrm{~d}(8 \mathrm{~h}-37 \mathrm{~d}) \\
42 \mathrm{~h}(1 \mathrm{~h}-156 \mathrm{~h}) \\
15 \mathrm{~d}(49 \mathrm{~h}-51 \mathrm{~d})\end{array}$ \\
\hline
\end{tabular}

The following mean values (weighted when indicated) were obtained for other variables. During mask CPAP the inflating pressure was $3.7 \mathrm{~cm} \mathrm{H}_{2} \mathrm{O}, \mathrm{FIO}_{2} 0.52, \mathrm{PaO}_{2} 10.4 \mathrm{kPa}\left(78.1 \mathrm{~mm} \mathrm{Hg}\right.$ ), and $\mathrm{PaCO}_{2}$ $9.0 \mathrm{kPa}(67.8 \mathrm{~mm} \mathrm{Hg})$. During mask ventilation the peak airway pressure was $12.4 \mathrm{~cm} \mathrm{H} \mathrm{H}_{2} \mathrm{O}$, end-expiratory pressure $0.3 \mathrm{~cm} \mathrm{H}_{2} \mathrm{O}$, respiratory frequency $43.8 \mathrm{cycles} / \mathrm{min}$, inspiration:expiration ratio $0.8: 1, \mathrm{FIO}_{2} 0.57, \mathrm{PaO}_{2} 10.5 \mathrm{kPa}(79.2 \mathrm{~mm} \mathrm{Hg})$, and $\mathrm{PaCO}_{2} 9.6 \mathrm{kPa}$ $(72.5 \mathrm{~mm} \mathrm{Hg})$. The $\mathrm{PaO}_{2}$ was easy to control, and though hypercapnia was common, it was usually not progressive, so that intubation could be avoided.

Three of the infants died, two from intraventricular haemorrhage and one (whom we were unable to wean from an endotracheal tube) from airway obstruction after tracheostomy for laryngeal oedema. Complications during treatment were few. One infant with hyaline membrane disease developed bilateral pneumothoraces while receiving a CPAP of $5 \mathrm{~cm} \mathrm{H}_{2} \mathrm{O}$. Ten infants developed slight gastric distension, usually when they were being ventilated with a peak airway pressure above $12 \mathrm{~cm} \mathrm{H}_{2} \mathrm{O}$ or when a CPAP or more than $5 \mathrm{~cm} \mathrm{H}_{2} \mathrm{O}$ was being used. Partly because of this distension and partly because we did not wish to overload the stomachs of very pre-term infants being weaned from ventilatory aids, nine infants were fed parenterally ${ }^{16}$ and their oral feeding was stopped or curtailed. None of the infants had any evidence of adverse pulmonary sequelae at follow-up. 


\section{Discussion}

The method of holding the facemask on was simple and the mask could be quickly placed in position or removed. It was easy to change from mask CPAP to mask ventilation. The problems previously encountered with the fixation of masks ${ }^{*} 1_{15}$ seemed to have been avoided. No facial oedema necessitating repositioning of the mask or distortion of the head occurred, presumably because the pressure holding the mask against the face was evenly distributed around the head. Complications of the technique were minimal. Gastric distension was never severe, but we suspect that it might have been had higher lunginflating pressures been used. Undetected vomiting and aspiration is a theoretical risk, but so far as we are aware it never occurred. We suggest that this technique may have advantages over other methods of applying CPAP or mechanical ventilation to infants mildly affected by respiratory illnesses and that it should be useful in avoiding endotracheal intubation or reducing the length of time that infants with more serious illnesses have to be intubated.

We are grateful to the staff of the neonatal unit for their devoted care of the infants, and to $\mathrm{Mr} \mathrm{C} \mathrm{A} \mathrm{N} \mathrm{Evans} \mathrm{for} \mathrm{the} \mathrm{photograph.}$
Requests for reprints should be addressed to: Dr E O R Reynolds, Department of Paediatrics, University College Hospital, London WC1.

\section{References}

${ }^{1}$ Gregory, G A, et al, New England fournal of Medicine, 1971, 284, 1333.

2 Dunn, P M, Proceedings of the Royal Society of Medicine, 1974, 67, 245.

${ }^{3}$ Barrie, H, Lancet, 1972, 1, 776.

+ Kattwinkel, J, et al, Pediatrics, 1973, 52, 132

5 Caliumi-Pelegrini, G, et al, Archives of Disease in Childhood, 1974, 49, 228

${ }^{6}$ Kattwinkel, J, et al, Fournal of Pediatrics, 1975, 86, 588

Rhodes, P G, and Hall, R T, Pediatrics, 1973, 52, 1.

${ }^{8}$ Helmrath, T A, Hodson, W A, and Oliver, T K, fournal of Pediatrics, 1970, 76, 202.

9 Swyer, P R, et al, paper presented to INSERM, Nancy, Sept 1973.

10 Chernick, V, and Vidyasagar, D, Pediatrics, 1972, 49, 753.

1 Bancalari, E, Gerhardt, T, and Monkus, E, Pediatrics, 1973, 52, 128

${ }_{12}$ Stahlman, M T, et al, fournal of Pediatrics, 1970, 76, 174.

13 Stern, L, et al, Canadian Medical Association fournal, 1970, 102, 595.

14 Vert, P, Andre, M, and Sibout, M, Lancet, 1973, 2, 319.

15 Pape, K, Armstrong, D, and Fitzhardinge, P, Pediatric Research, 1975, 9, 383.

16 Shaw, J C L, Pediatric Clinics of North America, 1973, 20, 333.

\title{
Effects of "natural oestrogen" replacement therapy on menopausal symptoms and blood clotting
}

\author{
JEAN COOPE, JEAN M THOMSON, L POLLER
}

British Medical fournal, 1975, 4, 139-143

eliminated in individual cases by oestrogen. The results of blood clotting studies indicated that natural oestrogen administration raised the levels of the extrinsic clotting factors VII and $X$ and accelerated the prothrombin time. The findings were similar to those observed after three months' synthetic oestrogen administration with oral contraception.

Long-term studies and epidemiological surveys of the clinical incidence of thrombotic and other sequelae are needed before large-scale oestrogen replacement treatment can be recommended.

two groups and given either three months' hormon treatment followed by three months' placebo or vice versa.

An appreciable amelioration of all symptoms on placebo made it difficult to assess the genuine value of oestrogen treatment during the period of study. Both groups made a dramatic clinical improvement during the first three months. Nevertheless, the symptoms of the 15 women who received oestrogen first returned after the cross-over to placebo without any suggestion of a placebo response. In contrast, the other group who took placebo first did not deteriorate after changing to oestrogen.

The menopausal index and the karyopyknotic index were not reliable guides to the need for oestrogen treatment. Hot flushes, however, were proportionately reduced on oestrogen and they seemed to be more readily

Group Practice, Bollington, Cheshire

JEAN COOPE, $\mathrm{MB}, \mathrm{CHB}$, general practitioner

Department of Haematology, Withington Hospital, Manchester M20 8LR

JEAN M THOMSON, PH.D., senior scientific officer

L POLLER, MD, FRCPATH, consultant haematologis!

\section{Introduction}

So-called "natural" oestrogens have been widely used in the treatment of menopausal symptoms, and long-term treatment is recommended by many workers. ${ }^{12}$ It is, however, important to decide whether this treatment is both effective and safe. The use of the term "natural" for oestrogens prepared from equine urine is questionable but we have used the term because the product is customarily described in this way.

Many adverse effects occur in women taking synthetic oestrogens. We have shown that oral contraceptive preparations containing synthetic oestrogen accelerate blood clotting and platelet aggregation, ${ }^{3}{ }^{4}$ which may cause the increased risk of thromboembolism. It has been suggested that natural oestrogens may be less harmful than synthetic preparations because they have less effect on the electrophoretic mobility of platelets. ${ }^{5}$ Claims have also been made that natural oestrogens do not accelerate blood clotting but these require confirmation by laboratory studies.

Our double-blind cross-over study in women given natural oestrogens and placebo alternately was designed to discover whether menopausal symptoms respond to oestrogens. Objective assessment of changes in weight, blood pressure, blood clotting, and platelet aggregation were performed during the study. 